
What do Household Surveys really tell us about risk, shocks, and risk management in the
developing world?

Rasmus Heltberg*, Ana María Oviedo*, and Faiyaz Talukdar ${ }^{\dagger}$

May 2, 2014

Abstract: We report on a project to explore empirical patterns in risk, shocks and risk management using recent household surveys with risk modules from 16 different developing countries. Natural disasters, health shocks, economic shocks, and asset loss are the most commonly reported types of shocks and, especially for the poor, often result in 'bad' coping responses that may perpetuate vulnerability. The information culled from these survey modules falls short of expectations in several ways.

\footnotetext{
* The World Bank. Corresponding author: Rasmus Heltberg, rheltberg@worldbank.org

${ }^{\dagger}$ Georgetown University.

The data and code used to generate the results in this paper are available on request from the authors. An earlier version of this paper was prepared as background work for the World Bank’s World Development Report 2014: Risk and Opportunity. We are grateful to Chris Barrett, Luc Christiaensen, Stefan Dercon, Garence Genicot, and Norman Loayza for useful comments and discussions. The findings, interpretations, and conclusions expressed in this paper are entirely those of the authors. They do not necessarily represent the views of the International Bank for Reconstruction and Development/World Bank and its affiliated organizations, or those of the Executive Directors of the World Bank or the governments they represent.
} 


\section{Risks, coping, and poverty}

Despite the solid economic growth and unprecedented reduction in extreme poverty during the last two decades in many parts of the developing world, risks that threaten peoples' lives, health, and livelihoods are still abundant. For example, while the risks leading to maternal and child mortality have declined dramatically, the incidence of natural disasters has steadily increased and the food, fuel, and financial crises that started in 2008 adversely affected millions (World Bank 2013).

A large body of literature has studied risks faced by households and the linkages between risk, shocks and poverty. Studies find that shocks can lead to sharp variations in consumption, depletion of productive assets, and human capital loss. ${ }^{1}$ Qualitative and quantitative studies alike have highlighted the adverse effects of major disasters and economic crises as well as everyday shocks such as death and illness of a (Heltberg and Lund 2009, Ainsworth et al. 2010, Heltberg et al. 2013). Studies also find that the pervasive presence of risk combined with lack of better risk management tools lead poor people to adopt low-risk, low-return technologies (Rosenzweig and Wolpin 1993, Dercon and Christiaensen 2011). The impact of shocks can be eclipsed by the costs of various ex-ante adjustments people make in the knowledge that there is risk (Morduch 1995, Ligon and Schechter 2003, Christiaensen and Subbarao 2005). Risk management tools such as microfinance, social protection, and preventative health can both mitigate poverty and serve as a springboard to enable pursuit of productive opportunities.

Studies of risk management by households and communities have often emphasised differences in the effectiveness of the available instruments depending on the source of risk. Studies in developing countries find that people lacking formal risk management tools often share risks within communities: households use informal credit and reciprocity-based networks to smooth consumption (Townsend 1994, Kochar 1995, Ligon 2002). Such risk sharing is only partially effective and households can suffer major devastation from shocks (Gertler and Gruber 2002, Fafchamps and de Weerdt, 2011). Some authors find that informal risk management often allow people to manage idiosyncratic risk relatively better than systemic (or covariate) risk which is common across communities and therefore harder to share (Dercon 2002, Gunther and Harttgen 2009, Hoogeveen et al. 2011). For example, Heltberg et al. (2013) using qualitative data find that informal mechanisms were quite inadequate to protect households exposed to the food, fuel and financial crises. Yet other studies find that idiosyncratic shocks are the most frequent and costly to people (Gertler and Gruber 2002, Kazianga and Udry 2006, Heltberg and Lund 2009).

There is as yet no established consensus on the relative frequency and severity of different sources of risk, in part because the literature has been based on a relatively limited number of surveys many of which are not nationally representative.

Findings on shock types and the strength of formal and informal risk management in different circumstances are needed to inform micro finance, social protection and other policies aimed to fight poverty and help people manage risk. Studies finding that idiosyncratic risk is less burdensome and better managed than systemic risk would imply that policy should focus on systemic risk, for example via better macroeconomic management and disaster risk management, rainfall insurance, and social protection that is responsive to crises and natural disasters. In contrast, studies finding that idiosyncratic shocks are more frequent and costly compared to systemic risk imply a more acute need for policies to help people manage idiosyncratic risk, for example by strengthening life and health insurance and access to financial tools.

In this paper, we report on a project that aimed to systematically explore patterns of shock exposure and coping from recent waves of household surveys containing modules designed to collect information on risk management. Our goals were to identify broad empirical patterns in risk, shocks and risk 
management by households and communities in the developing world, and also to assess the usefulness of the data for informing risk management policies and make recommendations for future data collection efforts.

Despite the heterogeneity across country surveys, risk modules attached to multi-purpose surveys had sufficient commonalities to enable pooling and cross-country analysis. Much of this data had not been previously analyzed, and, to our knowledge, this is the first effort in combining a large number of surveys of this kind.

This paper attempts to contribute to the literature on risk management in developing countries in three different ways:

1. It documents the data and analytical criteria to do a comparative analysis on self-reported risk and risk management. While the survey instruments used in the project share similar purposes and some broad features, there is much heterogeneity. This led us to define of broad groupings of response categories that would ensure a minimum level of data comparability. We ended with a selection of 16 recent household surveys with risk modules from 16 different developing countries.

2. It describes a fairly rich set of findings on risk management that emerge from our systematic and comparative meta-analysis of the 16 surveys. We analyze responses to questions about the occurrence of various types of shocks and how households coped. We also touch on policy implications of the findings.

3. It critically assesses this type of data. Several shortcomings and weaknesses in the data became clear during the project. We reflect on these shortcomings and propose some potential avenues for future data collection efforts.

We find that both idiosyncratic and systemic sources of risk are frequent. Health shocks (death and illness) are universally prevalent, while systemic shocks, in particular drought and other disaster events, tend to be more pronounced in rural than in urban areas. People affected by shocks commonly respond with a mix of consuming fewer food and nonfood items, working more, seeking credit and assistance from formal and informal sources, and relying on savings and sales of assets. Poverty is often associated with more damaging coping mechanisms, such as reducing food consumption or selling productive assets.

We also conclude that the information culled from these surveys falls short of expectations in several ways. Heterogeneity in survey design compromised the ability to compare detailed findings across surveys beyond broad patterns. Response categories for shocks and coping were arbitrary and incomplete in many surveys. The surveys tend to offer superficial information on how shocks, coping and outcomes such as poverty are linked. Insights on the effectiveness of common risk management tools and policies such as microfinance, social protection, market insurance, and preventative health are at best limited. They are silent on risk perceptions and on the obstacles to risk management (for example, why people don't save up more or take steps to prevent health issues). Some of these shortcomings might be resolved through changes to survey design while others would require different research approaches.

The remainder of this paper starts by introducing the data while section 3 presents findings on shocks, section 4 presents findings on coping responses, section 5 reflects on limitations in the data and section 6 summarises the conclusions. 


\section{Data}

We review and analyze household survey data from Afghanistan, Bangladesh, China, Iraq, Laos, Malawi, Maldives, Mexico, Nigeria, Peru, Sudan, Tajikistan, Tanzania, Uganda, Uzbekistan and Vietnam. Surveys comprise a mix of Living Standard Measurement Surveys (LSMS), budget surveys, and special-purpose surveys (often focused on social protection). The main selection criterion was the availability of a module asking respondents to list shocks they have experienced. In addition, we gave priority to recent (since 2000) and nationally representative surveys and avoided well-researched data such as the ICRISAT panel. The selected surveys are shown in Table 1.

*Table $1 *$

*Table $2 *$

Table 2 presents a summary of the types of information on shocks and coping collected by each survey. As can be inferred, the design of the shock module varies significantly across countries. We constructed broad categories of shock types (health, employment, price shocks and so on) and of coping responses (work more, consume less, and so on). This allowed us to tabulate results in categories that are common across surveys.

We group survey responses into broad categories that permit us to compare across countries. Price shocks comprise input, output, and food price shocks. Disasters include drought, water scarcity for various reasons, flood, crop disease, storms, and more. Employment shocks comprise reduced earnings and wages and loss of job. Asset shocks denote loss of land, house, livestock, and machinery for various reasons (of which livestock disease is one of the most common). Health shocks comprise death, illness, accidents, and disability, while crime and safety comprise common theft and violence of all kinds. Household breakup includes separations but also incidents involving the police and other authorities.

Our study of coping responses is made complicated by the fact that response categories were not uniform. We use two different analytical strategies to achieve a degree of comparability across countries. First, we group coping responses into comparable functional categories based on whether households used assets, savings, credit, employment, consumption or assistance to help them cope (Heltberg et al., 2012 used similar categories). Second, we distinguish 'good' and 'bad' forms of coping. 'Good' coping comprises use of savings, credit, asset sales, additional employment and migration, and assistance. 'Bad' coping comprise responses that may increase vulnerability to future shocks and include health and education expenses, productive asset sales, and consumption reductions. This second distinction is inspired by the notion that the rationale for many policies in social protection, disaster risk reduction, and micro-insurance is to avoid 'bad' coping that may perpetuate poverty.

The next two sections present the results for shocks and coping, respectively. 


\section{Frequency and magnitude of shocks}

This section presents our findings on the number and types of shocks reported by respondents. The share of households reporting any shock varies significantly across countries; in some cases defying explanation. Table 3 reports the percentage of households that reported experiencing a shock in any of the eight broad categories created for comparative purposes. Disasters, asset losses, and health shocks appear to be the most commonly reported shocks, which is consistent with most of the literature on risk.

Several sources of potential non-comparability and measurement error merit discussion. The percentage of households reporting shocks seems surprisingly low in fragile states like Afghanistan and Iraq (particularly in the category of crime and safety). In Bangladesh, the questionnaire design omitted disasters. There is large variation in the percentage of households reporting any shock across countries (Table 4). And although surveys with 5 year recall tend to show a higher incidence of shocks than surveys with one year recall, that difference is lower than expected. It seems clear that not only objective variation in risk levels, but also survey design, survey implementation, and respondents' subjective interpretation of shocks affect the observed cross-country patterns in Table 3 and 4. Sources of measurement error within each survey are less obvious. One might expect response bias toward more financially and/or emotionally distressing experiences presumably correlated with memory saliency such as health shocks and big losses. This being said, we conducted a limited validation using the Tanzania surveys self-reported price shocks (which arguably one would not expect to be associated with distress or be highly salient) and found them to correlate closely with relevant food price statistics obtained from official sources. $^{2}$ 
*Table 3*

*table $4 *$

Looking within countries, rural households report more shocks than do urban ones. Rural households report a higher number of shocks on average (with the exception of Maldives and Uzbekistan) and are more likely to report at least one shock than urban households (Table 4), especially in the lowest quintile (true in 9 countries out of 15). The urban-rural difference is particularly strong in Afghanistan, Lao PDR and Malawi. We conclude that rural areas and rural livelihoods often are more risk prone than urban ones.

The Tanzania survey asked people whether a given shock was also experienced by other members of the community. This permits an assessment of how covariate different shock types are (Figure 1). The results confirm our priors: food price hikes, water scarcity, droughts, floods, and crop disease are mostly covariate; death, illness, crime, household breakup, and business failures are mostly idiosyncratic. However, the results also indicate that, in practice, the distinction between covariate and idiosyncratic risk is rather graduated: most types of agricultural risk, for example, tend to affect the entire village, but sometimes they affect many farmers, and occasionally just a single farmer. Overall, six of the seven most commonly reported shocks are mostly covariate, reflecting the agricultural nature of life in Tanzania.

*figure $1 *$

Disasters, health shocks, economic shocks, and asset loss are the most commonly reported types of shocks across countries (Table 3). Natural disasters such as drought, water scarcity, and flooding are among the most frequently reported type of shock in all countries for which we have data. Disaster shocks are more prevalent in rural areas where they are often the single most frequent type of shock (see Table 5 showing the pairwise correlations between shock type and rural/urban location that were statistically significant). In Lao PDR, Malawi and Vietnam, almost half of the poorest rural population suffers from disasters. Drought is the most common type of natural disaster, with flooding and crop disease also important. Although more prevalent in rural areas, they remain high risks in urban areas as well. Where surveys (Malawi, Nigeria and Tanzania) ask respondents to rank shocks by severity, rural households in particular tend to rank disasters highly (not shown in tables). In rural Malawi, for example, nearly three-fifths of all households rank disasters as the most severe shock experienced.

Death, illness, and accidents are another major risk category that ranks high in all countries with shock data, confirming earlier findings (Heltberg and Lund 2009, Wagstaff and Lindelow 2010). Health shocks is the most commonly reported shock type in Maldives, Mexico, and Nigeria; second only to natural disasters in rural India and in Peru and Uganda; and second to asset loss in rural China. Health shocks are ranked as severe in Malawi and Tanzania, where they are the most severe shock for more than half of the households who report them.

Price shocks are also very common: they are the most commonly reported type of shock in Tanzania and Vietnam, and the second-most common in Malawi. This is hardly surprising since several of these surveys were conducted during the height of the food price crises (Vietnam during the 2008 crisis and Malawi, Peru, Nigeria and Tanzania during the food price spikes in 2010/11); these numbers confirm other studies finding widespread impacts of the food price crisis on both rural and urban households, particularly in Africa (World Bank 2011, Heltberg et al. 2012).

Compared to price shocks, far fewer households report loss of employment as a major shock, perhaps because there is so little regular employment to begin with. Employment shocks are more commonly 
reported in urban areas (Table 5). Loss of assets such as farm equipment, livestock, stored harvest and durable goods is the fourth major type of shock in these surveys and can result from a wide variety of risks. Asset loss is almost always more common in rural than in urban areas (Table 5), and it is the most common type of shock in rural China, Lao PDR, Mexico, and Sudan.

\section{*table 5*}

Other types of shocks are important only in specific countries. Crime and violence, including common theft, are fairly common in some places such as Iraq, rural Afghanistan, and the African countries, and relatively minor in most other places. Of course, this frequency data do not show the impact of shocks, and there is reason to believe that crime and, in particular, collective forms of violence may have deeper repercussions on trust, social cohesion, and business climate than many other types of risk (Petesch 2013). Household issues is a residual category that includes divorce or separation, dowry and marriage payments, legal issues, getting arrested, and having trouble with the police. In a few places such as Tanzania and Uzbekistan, these numbers are relatively high.

We conclude that disasters, health, and price shocks as well as asset losses are the most frequently reported types of shocks to households in this multicountry sample and that idiosyncratic and systemic risk both are important. 
We use regression analysis to link shock reporting rates to key household characteristics, namely: the size of the household, the gender, occupation and education level of the household head, share of working household members, region (rural or urban), the first common factor of a number of variables capturing dwelling quality (roof, floor walls, and the type of cooking equipment) and access to services (piped water, and distance to the nearest school, health facility, city, and paved road), and economic conditions measured by quintiles of per capita consumption. We are interested in how household's internal conditions are related to the household's likelihood to report shocks. We run OLS instead of a binary outcome model (such as probit) or a latent variable model (such as multinomial probit) in order to minimise the number of imposed assumptions, particularly on the distribution of the error term. By merely reporting correlates, OLS provides coefficients that are more robust to specification errors.

We use the following model:

$$
y_{i}=a_{0 i}+a_{1 i} X_{i}+a_{2} d+\varepsilon_{i}
$$

where $y_{i}$, our dependent variable, is a dummy that captures the type of shock experienced by the household, and depends on a set of household and household head characteristics $X_{i}$, and district-level fixed effects $d$. Unobservables are grouped into the error term $\varepsilon_{i}$. We run the regressions on the entire sample of survey respondents in each country.

Regressing a host of covariates pertaining to household (and individual level) characteristics on shock incidence yields some consistent results across countries; the main (significant) results are listed below: ${ }^{3}$

- Household size is positively correlated with shock reporting rates across the board, as larger households are exposed to more shocks from multiple dimensions. This is largely the case across the typology of shocks considered with the exception of crime and safety shocks (which were negatively or not correlated with household size for most countries).

- Female headed households are more likely to report a shock, particularly in the case of health shocks and natural disasters (Mexico is an exception).

- Households whose heads are employed in agriculture report more shocks on average, particularly shocks from price of inputs, outputs or staple food items, and natural hazards. Employment shocks, on the other hand, are more frequently reported by households whose heads are employed in non-agricultural sectors in some survey countries such as Afghanistan and Uzbekistan.

- The education level of the household head is negatively correlated with shock reporting rates, particularly when dealing with asset or crop loss, in some countries.

- Rural households report more systemic shocks, with no clear pattern for idiosyncratic shocks.

- Infrastructure (common factor): households with lower values of this variable are more likely to report suffering loss of assets, disasters, crime and violence, and health shocks.

- Wealth: poorer households are more likely to report experiencing disasters, asset losses, and household breakup.

\section{Households use a wide variety of coping responses, often not very appealing ones}

This section presents findings on how households respond to shocks. Figure 2 (for the countries with the most directly comparable data) shows that households commonly respond to shocks with a mix of 
consuming fewer food and nonfood items, working more, seeking credit and assistance from both formal and informal sources, and relying on savings and sales of assets.

*figure $2 *$

*table 6*

The surveys indicate substantial use of 'good' coping, including savings (Table 6). Rural households generally report a higher reliance on sales of non-productive assets such as furniture, basic appliances and durable items than urban households do; this is most noticeable in the case of Bangladesh and Uganda where the rural reporting rate is four times as high as with urban households. Migration is also a common form of coping in some countries, particularly amongst rural households; this is consistent with migratory patterns reported in most of the migration literature (Fields 1975, Lucas 1997). In rural China and Tajikistan, every other household reports having a family member who has had to take on additional employment after a shock, primarily through migration. There is frequent use of formal and informal credit; in Bangladesh, 3 out of every 4 households hit by a shock used credit to cope; in rural Iraq, half did so. Informal assistance, both monetary and non-monetary, from friends, relatives, and neighbors is also common, especially in some of the African and East European countries.

Turning to 'bad' (or costly) coping, reductions in food and non-food consumption are common. Some households also rely on sales of productive assets, which could reduce future earnings; we see this particularly in the case of rural Afghanistan, Bangladesh, Nigeria, Sudan and Tajikistan. In contrast, reductions in household expenditure on health and education are relatively uncommon in most countries, with the exception of Tajikistan. 
We use ordinary least squares regressions to link the type of coping response to the type of shock reported and the same key household characteristics described for the regressions on shock incidence.

We use the following model:

$$
y_{i}=b_{0 i}+b_{1 i} s_{i}+b_{2 i} X_{i}+b_{3} d+\epsilon_{i}
$$

where $y_{i}$, our dependent variable, is a dummy that captures the type of coping strategy used by the household, and depends on the occurrence of any shock $s_{i}$, a set of household and household head characteristics $X_{i}$, and district-level fixed effects $d$. Unobservables are grouped into the error term $\epsilon_{i}$. We run the regressions on the set of households who have experienced at least one shock.

Broadly speaking, the main factors associated to the likelihood of reporting a shock are the following:

- Gender of the household head: There is no strong cross-country pattern of female-headed households using more costly coping strategies. Still, in Afghanistan, female-headed households are more likely to use savings and sell durable goods in response to shocks; whereas in Malawi they are more likely to increase their labor supply, sell productive assets or reduce food consumption. In Uganda, they are more likely to resort to credit; while in Uzbekistan they are less likely to do so (they also report using their savings and labor supply relatively more).

- Occupation of the household head: The sale of productive assets is reported as a significant coping strategy for farming households in 5 out of 12 countries. In Sudan, Uganda and Vietnam, farming households also report using their savings and in Uganda, Uzbekistan and Vietnam use of assistance (they are less likely to report using assistance in Afghanistan and Nigeria). Increasing labor supply is a common response to shocks for rural households (typically through migration to urban areas) in five countries, while in Afghanistan, Peru, and Sudan farming households are less likely to increase their labor supply.

- Household size: Controlling for other factors, larger households are more likely to rely on 'good' forms of coping (mostly using savings or selling assets, and in some cases obtaining credit). In Afghanistan, Iraq and Vietnam, however, larger households are more likely to sell productive assets. In Mexico and Uzbekistan, large households are less likely to receive assistance.

- Wealth: Richer households generally are more likely to use 'good' coping practices, although contrasting results are observed in the case of credit (Mexico, Uzbekistan and Vietnam). Richer households in Afghanistan, China and Iraq; and poorer households in Sudan and Uzbekistan are more likely to increase their labor supply either by migrating or by increasing the hours worked. Poorer households (except in China and Vietnam) are more likely to reduce the quantity and quality of consumption. In Afghanistan and Uganda richer households are more likely to rely on assistance from friends, family, the community, and NGOs, but the same is true for poorer households in Sudan and Vietnam. The sale of productive assets is more likely for richer households in China and Tajikistan, and for poorer households Sudan and Uzbekistan.

To gain a deeper understanding of the mechanisms behind risk management, in particular whether households are able to use adequate ex-ante risk management tools, we try to identify throughout the household surveys variables that capture the concepts of Knowledge, Protection, and Insurance (World 
Bank, 2013). These variables typically cover access to information, access to insurance (for instance bank accounts), and access to prevention services and practices (such as health services).

Unfortunately, very few of these surveys collect any information at all that is useful to gauge the extent of ex-ante risk management. Only in surveys from three countries (Malawi, Nigeria and Uganda) were we able to identify variables measuring access to various formal risk management tools: cash or food transfers, income generating schemes and public loan schemes, access to bednets and preventive healthcare services, and access to informal and formal credit and savings arrangements.

While these indicators are suitable proxies for an enabling environment to conduct efficient risk management, by themselves they provide a very incomplete picture of the ability of households to adequately prepare for risk. In addition, correlates between these indicators and either shocks or coping mechanisms cannot reveal whether such an environment causes risk management to improve or not (and with no counterfactual, such assessment is not possible).

Our results suggest a mild association between access to risk management, shocks, and the quality of coping. Specifically, in Malawi and in Nigeria households that benefit from access to safety nets are less likely to report increasing their labor supply. In addition, in Nigeria these households are less likely to report using their savings, and reducing consumption and human capital investment. Second, in Malawi, households that report using bednets also report fewer health shocks, whereas the opposite is true in Nigeria and Uganda. Finally, in Uganda, households with access to financial services are more likely to report use of credit and assistance.

\section{Implications for data collection and analysis}

Reflecting on the quality and usefulness of self-reported risk management data, we conclude that the self-reported survey modules on risk fulfill to some extent their purpose of providing relevant information on shocks and coping. For example, the data show that health shocks and disasters are frequent, but offer little on how households prepare for these risks, and hence which practices could be reinforced or changed. Hence, these modules can be greatly improved along two important lines of research, and more importantly, to be useful as policy tools. The first line is gaining a deeper understanding of risk exposure, incidence and cost; whereas the second one involves more elaborate ways to understand and measure the quality of ex-ante risk management, or preparation (World Bank 2013).

The following modifications to survey instruments could improve our understanding of risk exposure and costs:

- Adoption of a harmonised format for shock and coping modules to use across countries would help ensure more complete data with comparable response categories.

- Better match of recall periods across modules within the survey so that, for example, information on health care and social protection can be linked to shocks and coping. 
- Ask which household members were subject to each shock. The Vietnam and Lao PDR surveys did this by explicitly asking about shock consequence for individual household members.

- Include more detail on access to credit and assistance. For example, asking whether the source of credit used to cope was formal or informal, a crucial distinction from a policy perspective.

- Include more detail on public and private assistance programs.

- Include perception questions similar to those used in the World Values Survey, for example: "Have you preferred not to go out at night for reasons of security?"4

- Include measures of the magnitude of the shock, in terms of costs incurred. This information is obtainable in principle, but may be hard to assess given errors in respondents' recall.

Still, to successfully manage risk, preparation has to improve (World Bank 2013). Hence, policies to reduce vulnerability need to be rooted in an understanding not only of key risks facing the poor and near-poor, but also of the constraints and obstacles to better risk management. It is frequently the case that risks are fairly well-understood and that simple cost-effective steps to address them are available and known but not carried out. Seen this way, the key bottleneck for better policy design may be less about risk information than with understanding the obstacles to better risk management, that is, the behavioral, cognitive, social, and political reasons for apathy operating at the level of individuals, households, communities, enterprises, and government.

Though many aspects of this risk management process may not be measurable through household surveys, some aspects of it could. For example, surveys can provide information on whether people know about their exposure to risks, and about the actions they can take to avoid shocks. They can also document households' protective actions such as engaging in low risk-low return strategies. Surveys could also ask people why they do not adopt risk management instruments when they are readily available.

Thus we recommend greater attention to assessing people's knowledge about risk and risk preparation, and obstacles to risk management. Such research may well go beyond collecting household-level data and require specialised instruments and a combination of quantitative and qualitative methods. It should focus on what forms of risk management exist in different contexts, and what is holding back families, communities, and societies from managing risk successfully.

\section{Conclusions}

This paper has compared and analyzed data from 16 different household surveys from 16 different developing countries with broadly similar but uncoordinated modules on risk and risk management.

Despite limitations in data comparability, we are able to identify broad patterns. Idiosyncratic and systemic (or covariate) sources of risk are both frequent. Health shocks (mostly idiosyncratic) are universally prevalent and one of the most frequently reported sources of shock in all surveys we looked at. There are also indications that survey respondents consider health shocks to have severe impacts. Various systemic shocks were also important, with drought and disaster events reported very frequently in particular in rural areas in most survey countries. On the whole, rural areas and rural livelihoods are 
more risk prone than urban ones. Price shocks and asset losses occurring for various reasons were also common. Other types of shocks were important only in specific countries. Crime and violence, including common theft, are fairly common occurrences in Iraq, the African countries, and rural Afghanistan and relatively infrequently reported elsewhere.

Households affected by shocks commonly respond with a mix of consuming fewer food and nonfood items, working more, seeking credit and assistance from formal and informal sources, and relying on savings and sales of assets. Poorer households are often more likely to reduce food and nonfood consumption when shocks occur. Our findings are broadly similar to other studies. For example, studying a panel sample in Tanzania's Kagera region, de Weerdt (2010) finds that people's degree of protection against illness and agricultural shocks - also the most important shocks in that survey-to be highly correlated to their chances of moving out of poverty. Policy approaches to improve risk management across multiple risks seem warranted.

The information culled from these surveys falls short of what would be desirable for well-informed risk management and social protection policy making. We recommend survey design be improved by adopting more complete and potentially standardised response categories for shocks and coping and providing better ways to link risk preparation, shocks, and coping responses to outcomes (poverty, wellbeing, children's education, and so on). Future surveys may also consider collecting more information on risk perceptions and the effectiveness of microfinance, social protection, market insurance, and preventative health; current practice is to ask about coverage (but not effectiveness) for some of these risk management instruments.

Finally, we propose more research on the obstacles to risk management. This research should address the reasons that households, communities, and societies often fail to adopt available measures against known risks. It would likely require specialised instruments beyond what can be included in a generalpurpose household survey. 


\section{References, tables and figures}

\section{References}

Ainsworth, M., Beegle, K., \& Koda, G. (2010). The Impact of Adult Mortality and Parental Deaths on Primary Schooling in North-Western Tanzania. Journal of Development Studies, 41 (3), 412-39.

Alderman, H., Hoddinott, J., \& Kinsey, B. (2006). Long Term Consequences of Early Childhood Malnutrition. Oxford Economic Papers, 58 (3), 450-74.

Ashraf, N., Karlan, D., \& Yin, W. (2006). Tying Odysseus to the Mast: Evidence from a Commitment Savings Product in the Philippines. Quarterly Journal of Economics, 121 (2), 635-72.

Banerjee, A.V., Cole, S., Duflo, E., \& Linden, L. (2007). Remedying Education: Evidence from Two Randomized Experiments in India. Quarterly Journal of Economics, 122 (3), 1235-64.

Beegle, K., Dehajia,R.H., \& Gatti, R. (2006). Child Labor and Agricultural Shocks. Journal of Development Economics, 81 (1), 80-96.

Bertrand, M., \& Mullainathan, S. (2001). Do People Mean What They Say? Implications for Subjective Survey Data. American Economic Review, 91 (2), 67-72.

Carter, M.R., Little, P.D., Mogues, T., \& Negatu, W. (2007). Poverty Traps and Natural Disasters in Ethiopia and Honduras. World Development, 35 (5), 835-56.

- (2004). Shocks, Sensitivity and Resilience, Tracking the Economic Impacs of Environmental Disaster on Assets in Ethiopia and Honduras. Wisconsin, BASIS.

Christiaensen, L.J., \& Subbarao, K. (2005). Towards an Understanding of Household Vulnerability in Rural Kenya. Journal of African Economies, 14 (4), 520-58.

De Weerdt, J. (2009). Moving out of Poverty in Tanzania: Evidence from Kagera. Journal of Development Studies, 46 (2), 331-49.

Dercon, S. (2002). Income Risk, Coping Strategies, and Safety Nets. World Bank Research Observer, 17 (2), 141-66.

. (2004). Growth and Shocks, Evidence from Rural Ethiopia. Journal of Development Economics, 74 (2), 309-29.

Dercon, S., Hoddinott, J., \& Woldehanna, T. (2012). Growth and Chronic Poverty: Evidence from Rural Communities in Ethiopia. Journal of Development Studies, 48 (2), 238-53.

Duflo, E., Dupas, P., Kremer, M., \& Sinei, S. (2006). Education and Hiv/Aids Prevention: Evidence 
from a Randomized Evaluation in Western Kenya. World Bank Policy Research Working Paper 4024, Washington, DC.

Fafchamps, Marcel and Joachim De Weerdt. (2011). Social Identity and the Formation of Health Insurance Networks. Journal of Development Studies, 47 (8), 1152-77.

Fields, G. (1975). Rural-Urban Migration, Urban Unemployment and Underemployment, and JobSearch Activity in LDCs. Journal of Development Economics, 2 (2), 165-87.

Gertler, P., \& Gruber, J. (2002). Insuring Consumption against Illness. American Economic Review, 92 (1), 51-70.

Gunther, I., \& Harttgen, K. (2009). Estimating Households Vulnerability to Idiosyncratic and Covariate Shocks: A Novel Method Applied in Madagascar. World Development, 37 (7), 1222-34.

Heltberg, R., Hossain, N., \& Reva, A. (2012). Living through Crises : How the Food, Fuel, and Financial Shocks Affect the Poor. New Frontiers of Social Policy. Washington, DC, World Bank.

Heltberg, R., Hossain, N., Reva, A., \& Turk, C. (2013). Coping and resilience during the food, fuel, and financial crises. Journal of Development Studies, 49 (5), 705-18.

Heltberg, R., \& Lund, N. (2009). Shocks, Coping, and Outcomes for Pakistan's Poor: Health Risks Predominate. Journal of Development Studies, 45 (6), 889-910.

Hoddinott, J., \& Kinsey, B. (2001). Child Growth in the Time of Drought. Oxford Bulletin of Economics and Statistics, 63 (4), 409-36.

Hoogeveen, J., Van der Klaauw, B. \& Van Lomwel, G. (2011). On the Timing of Marriage, Cattle, and Shocks. Economic Development and Cultural Change, 60 (1), 121-54.

Jodha, N.S. (1978). Effectiveness of Farmers’ Adjustments to Risk. Economic and Political Weekly, 13 (25), A38-A41+A43-A48.

Kazianga, H, \& Udry, U. (2006). Consumption Smoothing? Livestock, Insurance and Drought in Rural Burkina Faso. Journal of Development Economics, 79 (2), 413-46.

Kochar, A. (1995). Explaining Household Vulnerability to Idiosyncratic Income Shocks. American Economic Review, 85 (2), 159-64.

Ligon, E. (2002). Targeting and Informal Insurance. United Nations University Wider Discussion Paper DP2002/08, World Institute for Development Economics Research.

Ligon, E., \& Schechter, L.. (2003). Measuring Vulnerability. Economic Journal, 113 (486), C95-C102.

Lucas, R.E.B. (1997). Internal Migration in Developing Countries. In Handbook of Population and Family Economics, edited by Mark Richard Rosenzweig and Oded Stark. Amsterdam ; New 
York, Elsevier.

Morduch, J. (1995). Income Smoothing and Consumption Smoothing. Journal of Economic Perspectives, 9 (3), 103-14.

Petesch, P. (2013). How Communities Manage Risks of Crime and Violence. Background paper for the World Development Report 2014.

Porter, C. (2012). Shocks, Consumption and Income Diversification in Rural Ethiopia. Journal of Development Studies, 48 (9), 1209-22.

Thai, T.Q. \& Falaris, E.M. (2014). Child Schooling, Child Health, and Rainfall Shocks: Evidence from Rural Vietnam. Journal of Development Studies, 50(7), 1025-1037.

Townsend, R.M. (1994). Risk and Insurance in Village India. Econometrica, 62 (3), 539-91.

(1995). Consumption Insurance - an Evaluation of Risk-Bearing Systems in Low-Income Economies. Journal of Economic Perspectives, 9 (3), 83-102.

Wagstaff, A. \& Lindelow, M. (2010). Are health shocks different? Evidence from a multi-shock survey in Laos. Policy Research Working Paper Series 5335, The World Bank.

World Bank. (2013). World Development Report 2014 Risk and Opportunity: Managing Risk for Development. Washington DC, The World Bank.

Yilma, Z., Mebratie, A., Sparrow, R., Abebaw, D., Dekker, M., Alemu, G. \& Bedi, A.S. (2014). Coping with shocks in rural Ethiopia. Journal of Development Studies, 50(7), 1009-1024.

Table 1: Surveys used in the study

\begin{tabular}{|l|l|l|l|l|l|l|}
\hline Survey Name & Year & $\begin{array}{l}\text { Sample Size } \\
\text { (number of } \\
\text { households) }\end{array}$ & $\begin{array}{l}\text { Level of } \\
\text { representation }\end{array}$ & $\begin{array}{l}\text { Recall } \\
\text { Period } \\
\text { (years) }\end{array}$ & $\begin{array}{l}\text { Shock } \\
\text { Module }\end{array}$ & $\begin{array}{l}\text { Coping } \\
\text { Module }\end{array}$ \\
\hline $\begin{array}{l}\text { Afghanistan National } \\
\text { Risk and Vulnerability } \\
\text { Survey }\end{array}$ & 2005 & 30,822 & National & 1 & $\mathrm{X}$ & $\mathrm{X}$ \\
\hline $\begin{array}{l}\text { Bangladesh Welfare } \\
\text { Monitoring Survey }\end{array}$ & 2009 & 14,000 & National & 1 & $\mathrm{X}$ & $\mathrm{X}$ \\
\hline China Rural Social & 2005 & 6,165 & Provincial & 1 & $\mathrm{X}$ & $\mathrm{X}$ \\
\hline
\end{tabular}




\begin{tabular}{|c|c|c|c|c|c|c|}
\hline Survey Name & Year & $\begin{array}{lr}\begin{array}{l}\text { Sample } \\
\text { (number }\end{array} & \begin{array}{r}\text { Size } \\
\text { of }\end{array} \\
\text { households) } & \end{array}$ & $\begin{array}{l}\text { Level of } \\
\text { representation }\end{array}$ & $\begin{array}{l}\text { Recall } \\
\text { Period } \\
\text { (years) }\end{array}$ & $\begin{array}{l}\text { Shock } \\
\text { Module }\end{array}$ & $\begin{array}{l}\text { Coping } \\
\text { Module }\end{array}$ \\
\hline \multicolumn{7}{|l|}{ Protection Survey } \\
\hline $\begin{array}{l}\text { Iraq Household Socio- } \\
\text { Economic Survey }\end{array}$ & $2006 / 07$ & 18,144 & National & 1 & $\mathrm{X}$ & $\mathrm{X}$ \\
\hline $\begin{array}{l}\text { Lao PDR Vulnerability } \\
\text { and Shocks Survey }\end{array}$ & 2008 & 600 & Provincial & 1 & $\mathrm{X}$ & $\mathrm{X}$ \\
\hline $\begin{array}{lr}\text { Malawi } & \text { Third } \\
\text { Integrated } & \text { Household } \\
\text { Survey } & \end{array}$ & 2010/11 & 12,271 & National & 1 & $\mathrm{X}$ & $\mathrm{X}$ \\
\hline $\begin{array}{l}\text { Maldives Vulnerability } \\
\text { and Poverty Survey }\end{array}$ & 2004 & 2,840 & National & 5 & $\mathrm{X}$ & $\mathrm{X}$ \\
\hline $\begin{array}{lll}\text { Mexico } & \text { Family } & \text { Life } \\
\text { Survey } & & \end{array}$ & 2002 & 8,440 & National & 5 & $\mathrm{X}$ & $\bar{X}$ \\
\hline $\begin{array}{ll}\text { Nigeria } & \text { General } \\
\text { Household Survey }\end{array}$ & 2010/11 & 4,986 & National & 5 & $\mathrm{X}$ & $\mathrm{X}$ \\
\hline $\begin{array}{l}\text { Peru Encuesta Nacional } \\
\text { de Hogares Sobre } \\
\text { Condiciones de Vida y } \\
\text { Pobreza }\end{array}$ & 2011 & 26,456 & National & 1 & $\mathrm{X}$ & $\mathrm{X}$ \\
\hline $\begin{array}{lr}\text { Sudan } & \text { National } \\
\text { Baseline } & \text { Household } \\
\text { Survey } & \end{array}$ & 2009 & 7,920 & National & 5 & $\mathrm{X}$ & $\mathrm{X}$ \\
\hline $\begin{array}{lr}\text { Tajikistan } & \text { Living } \\
\text { Standards } & \text { Measurement } \\
\text { Survey }\end{array}$ & 2009 & 1,500 & National & 1 & & $\mathrm{X}$ \\
\hline $\begin{array}{l}\text { Tanzania National Panel } \\
\text { Survey }\end{array}$ & 2010/11 & 3,924 & National & 5 & $\mathrm{X}$ & \\
\hline
\end{tabular}




\begin{tabular}{|l|l|l|l|l|l|l|}
\hline Survey Name & Year & $\begin{array}{l}\text { Sample Size } \\
\text { (number of } \\
\text { households) }\end{array}$ & $\begin{array}{l}\text { Level of } \\
\text { representation } \\
\text { Period } \\
\text { (years) }\end{array}$ & $\begin{array}{l}\text { Shock } \\
\text { Module }\end{array}$ & $\begin{array}{l}\text { Coping } \\
\text { Module }\end{array}$ \\
\hline $\begin{array}{l}\text { Uganda National } \\
\text { Household Survey }\end{array}$ & $2009 / 10$ & 6,800 & National & 1 & $\mathrm{X}$ & $\mathrm{X}$ \\
\hline $\begin{array}{l}\text { Uzbekistan Regional } \\
\text { Panel Survey }\end{array}$ & 2005 & 2,948 & National & 1 & $\mathrm{X}$ & $\mathrm{X}$ \\
\hline $\begin{array}{l}\text { Vietnam Household } \\
\text { Living Standard Survey }\end{array}$ & 2008 & 45,945 & National & 1 & $\mathrm{X}$ & $\mathrm{X}$ \\
\hline
\end{tabular}


Table 2: Typology of questions asked in shock and coping modules

\begin{tabular}{|c|c|c|c|c|c|c|c|c|c|c|c|}
\hline & $\begin{array}{l}\text { Experie } \\
\text { nced } \\
\text { shock }\end{array}$ & $\begin{array}{l}\text { Sho } \\
\text { ck } \\
\text { timi } \\
\text { ng }\end{array}$ & $\begin{array}{l}\text { Multi } \\
\text { ple } \\
\text { shock } \\
\text { s }\end{array}$ & $\begin{array}{l}\text { Cos } \\
\text { ts } \\
\text { (ty } \\
\text { pe } \\
\text { of } \\
\text { loss } \\
\text { ) }\end{array}$ & $\begin{array}{l}\text { Costs } \\
\text { (curren } \\
\text { cy) }\end{array}$ & $\begin{array}{l}\text { Did } \\
\text { others } \\
\text { experie } \\
\text { nce it }\end{array}$ & $\begin{array}{l}\text { Shoc } \\
k \\
\text { Sever } \\
\text { ity }\end{array}$ & $\begin{array}{l}\text { Individ } \\
\text { ual } \\
\text { who } \\
\text { was } \\
\text { affecte } \\
\text { d }\end{array}$ & $\begin{array}{l}\text { Has the } \\
\text { househ } \\
\text { old } \\
\text { recover } \\
\text { ed? }\end{array}$ & $\begin{array}{l}\text { Copi } \\
\text { ng } \\
\text { type }\end{array}$ & $\begin{array}{l}\text { Ranki } \\
\text { ng of } \\
\text { coping } \\
\text { respon } \\
\text { ses }\end{array}$ \\
\hline $\begin{array}{l}\text { Afghani } \\
\text { stan }\end{array}$ & $\mathrm{x}$ & & & & & & $\mathrm{x}$ & & $\mathrm{x}$ & $\mathrm{x}$ & \\
\hline $\begin{array}{l}\text { Banglad } \\
\text { esh }\end{array}$ & $\mathrm{x}$ & & & & & & & & & $\mathrm{x}$ & \\
\hline China & $\mathrm{x}$ & & & $\mathrm{x}$ & $\mathrm{x}$ & & & & $\mathrm{x}$ & $\mathrm{x}$ & \\
\hline Iraq & $\mathrm{x}$ & & & & & & & & & $\mathrm{x}$ & \\
\hline $\begin{array}{l}\text { Lao } \\
\text { PDR }\end{array}$ & $\mathrm{x}$ & $\mathrm{x}$ & & $\mathrm{x}$ & $\mathrm{x}$ & & & & $\mathrm{x}$ & $\mathrm{x}$ & $\mathrm{x}$ \\
\hline Malawi & $\mathrm{x}$ & & & $\mathrm{x}$ & $\mathrm{x}$ & & $\mathrm{x}$ & & & $\mathrm{x}$ & $\mathrm{x}$ \\
\hline $\begin{array}{l}\text { Maldive } \\
\text { s }\end{array}$ & $\mathrm{x}$ & $\mathrm{x}$ & $\mathrm{x}$ & $\mathrm{x}$ & $\mathrm{x}$ & & & & & $\mathrm{x}$ & \\
\hline Mexico & $\mathrm{x}$ & $\mathrm{x}$ & $\mathrm{x}$ & & & & & $\mathrm{x}$ & & $\mathrm{x}$ & \\
\hline Nigeria & $\mathrm{x}$ & $\mathrm{x}$ & $\mathrm{x}$ & & & & $\mathrm{x}$ & $\mathrm{x}$ & & $\mathrm{x}$ & \\
\hline Peru & $\mathrm{x}$ & & & $\mathrm{x}$ & $\mathrm{x}$ & & & & $\mathrm{x}$ & $\mathrm{x}$ & \\
\hline Sudan & $\mathrm{x}$ & & & $\mathrm{x}$ & & & $\mathrm{x}$ & & & $\mathrm{x}$ & \\
\hline $\begin{array}{l}\text { Tajikist } \\
\text { an }\end{array}$ & & & & & & & & & & $\mathrm{x}$ & \\
\hline Tanzani & $\mathrm{x}$ & $\mathrm{x}$ & & $\mathrm{x}$ & $\mathrm{x}$ & $\mathrm{x}$ & $\mathrm{x}$ & & & & \\
\hline
\end{tabular}




\begin{tabular}{|l|l|l|l|l|l|l|l|l|l|l|l|}
\hline $\mathrm{a}$ & & & & & & & & & & & \\
\hline Uganda & $\mathrm{x}$ & $\mathrm{x}$ & & $\mathrm{x}$ & $\mathrm{x}$ & & & & & $\mathrm{x}$ & \\
\hline $\begin{array}{l}\text { Uzbekis } \\
\tan \end{array}$ & $\mathrm{x}$ & & & & & & $\mathrm{x}$ & & $\mathrm{x}$ & $\mathrm{x}$ & $\mathrm{x}$ \\
\hline Vietnam & $\mathrm{x}$ & $\mathrm{x}$ & & & $\mathrm{x}$ & & & $\mathrm{x}$ & $\mathrm{x}$ & $\mathrm{x}$ & \\
\hline
\end{tabular}


Table 3: Percentage of all households reporting the following shocks

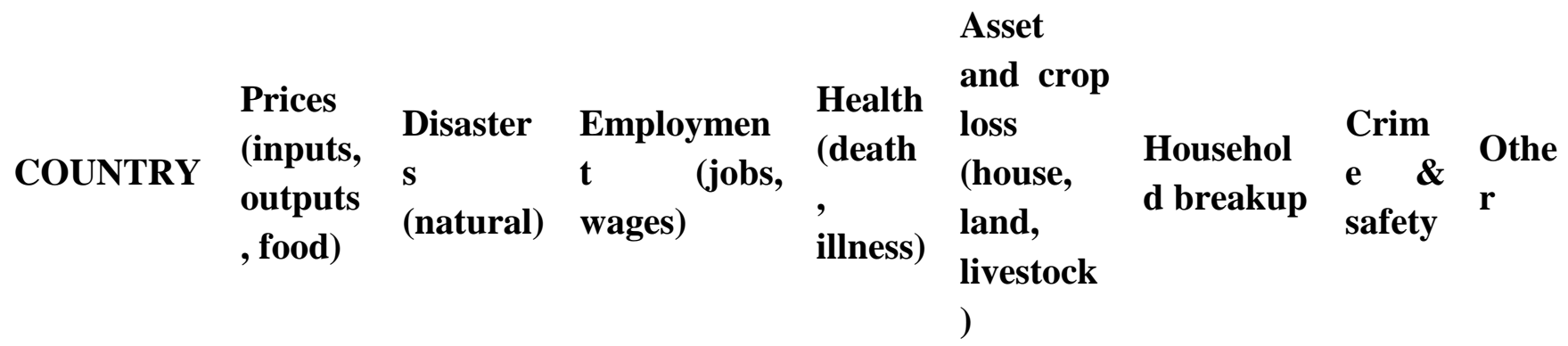

Surveys with 1 year recall period

Afghanista

\begin{tabular}{|c|c|c|c|c|c|c|c|c|}
\hline $\mathbf{n}$ & 2.2 & 34.2 & 4.4 & 11.5 & 15.8 & - & 4.9 & - \\
\hline Bangladesh & - & - & 2.8 & 4.9 & 4.1 & 2.5 & 0.7 & 4.3 \\
\hline China & - & - & 0.6 & 11.1 & 25.2 & 2.6 & 1.9 & 3.1 \\
\hline Iraq & - & - & 10.1 & 2.0 & - & - & 8.1 & 2.7 \\
\hline Lao PDR & 5.3 & 18.5 & 5.0 & 25.2 & 23.5 & 0.6 & 3.5 & - \\
\hline Malawi & 32.8 & 38.8 & 3.1 & 13.9 & 2.3 & 7.2 & 8.5 & 3.1 \\
\hline Peru & - & 6.7 & 4.2 & 8.8 & - & 0.8 & 3.3 & 1.7 \\
\hline Uganda & 1.5 & 32.4 & 1.4 & 11.4 & 0.6 & - & 13.9 & 2.6 \\
\hline Uzbekistan & - & - & 38.6 & 20.1 & 3.5 & 9.8 & 4.6 & 7.8 \\
\hline \multicolumn{9}{|c|}{ Surveys with 5 year recall period } \\
\hline Maldives & - & - & 0.9 & 14.5 & 1.6 & 0.8 & - & - \\
\hline Mexico & - & 1.4 & 8.0 & 13.4 & 4.7 & - & 1.4 & - \\
\hline Nigeria & 6.5 & 5.5 & 3.9 & 13.7 & 4.1 & 0.7 & 2.8 & 1.0 \\
\hline Sudan & - & 33.7 & - & 25.7 & 32.7 & - & 5.6 & 2.4 \\
\hline Tanzania & 43.5 & 34.2 & 4.0 & 46.4 & 7.7 & 18.4 & 15.9 & 3.4 \\
\hline
\end{tabular}


Table 4: Percentage of surveyed households reporting the incidence of single/multiple distinct shocks over the specified recall period

\begin{tabular}{|c|c|c|c|c|c|c|c|c|}
\hline \multirow[t]{2}{*}{ COUNTRY } & \multirow[t]{2}{*}{$\begin{array}{l}\text { Recall } \\
\text { Period }\end{array}$} & \multicolumn{2}{|c|}{$\begin{array}{l}\text { Experienced a } \\
\text { single shock }\end{array}$} & \multicolumn{2}{|c|}{$\begin{array}{l}\text { Experienced } \\
\text { multiple } \\
\text { shocks }\end{array}$} & \multicolumn{2}{|c|}{$\begin{array}{c}\text { Mean number } \\
\text { of shocks } \\
\text { experienced }\end{array}$} & \multirow[t]{2}{*}{$\begin{array}{c}\text { Difference in } \\
\text { mean number of shocks } \\
\text { across regions }\end{array}$} \\
\hline & & Urban & Rural & Urban & Rural & Urban & Rural & \\
\hline \multirow[t]{2}{*}{ Afghanistan } & 1 year & 8.26 & 9.76 & 8.12 & 39.14 & 0.34 & 1.36 & -1.01 \\
\hline & & {$[.003]$} & {$[.002]$} & {$[.003]$} & {$[.004]$} & [.014] & {$[.013]$} & {$[.019]$} \\
\hline \multirow[t]{2}{*}{ Bangladesh } & 1 year & 11.09 & 11.53 & 2.92 & 4.43 & 0.17 & 0.21 & -0.04 \\
\hline & & {$[.006]$} & {$[.002]$} & {$[.003]$} & {$[.002]$} & [.009] & {$[.006]$} & {$[.006]$} \\
\hline \multirow[t]{2}{*}{ China } & 1 year & \multirow{2}{*}{\multicolumn{2}{|c|}{$\begin{array}{l}25.94 \\
{[.006]}\end{array}$}} & \multirow{2}{*}{\multicolumn{2}{|c|}{$\begin{array}{l}11.61 \\
{[.004]}\end{array}$}} & \multirow{2}{*}{\multicolumn{2}{|c|}{$\begin{array}{c}0.53 \\
{[.010]}\end{array}$}} & N/A \\
\hline & & & & & & & & 1018 \\
\hline \multirow[t]{2}{*}{ Iraq } & 1 year & 9.00 & 8.24 & 8.00 & 6.84 & 0.34 & 0.25 & 0.09 \\
\hline & & {$[.004]$} & {$[.005]$} & {$[.004]$} & {$[.006]$} & [.017] & [.017] & {$[.024]$} \\
\hline \multirow[t]{2}{*}{ Lao PDR } & 1 year & 22.48 & 36.05 & 11.90 & 36.04 & 0.52 & 1.20 & -0.68 \\
\hline & & [.039] & {$[.033]$} & {$[.027]$} & [.033] & {$[.075]$} & {$[.071]$} & [.103] \\
\hline \multirow[t]{2}{*}{ Malawi } & 1 year & 21.94 & 25.73 & 17.29 & 43.70 & 0.69 & 1.61 & -0.93 \\
\hline & & [.019] & {$[.006]$} & {$[.014]$} & [.007] & {$[.036]$} & {$[.022]$} & {$[.042]$} \\
\hline \multirow[t]{2}{*}{ Peru } & 1 year & 19.24 & 32.66 & 1.34 & 1.87 & 0.22 & 0.37 & -0.15 \\
\hline & & {$[.005]$} & {$[.008]$} & {$[.001]$} & {$[.002]$} & [.005] & {$[.008]$} & {$[.009]$} \\
\hline \multirow[t]{2}{*}{ Uganda } & 1 year & 26.78 & 40.62 & 6.34 & 18.12 & 0.45 & 0.87 & -0.42 \\
\hline & & [.029] & [.019] & [.015] & [.015] & [.054] & [.039] & {$[.067]$} \\
\hline \multirow[t]{2}{*}{ Uzbekistan } & 1 year & 26.82 & 24.71 & 21.69 & 18.66 & 0.80 & 0.71 & 0.09 \\
\hline & & {$[.013]$} & [.011] & {$[.012]$} & [.010] & [.029] & {$[.026]$} & [.039] \\
\hline \multirow[t]{2}{*}{ Maldives } & 5 years & 15.96 & 15.45 & 4.56 & 1.11 & 0.27 & 0.18 & 0.09 \\
\hline & & {$[.021]$} & [.007] & [.012] & {$[.002]$} & [.034] & {$[.008]$} & [.026] \\
\hline \multirow[t]{2}{*}{ Mexico } & 5 years & 21.13 & 22.08 & 5.81 & 8.81 & 0.34 & 0.43 & -0.09 \\
\hline & & [.009] & [.010] & {$[.005]$} & [.007] & [.014] & [.019] & [.024] \\
\hline \multirow[t]{2}{*}{ Nigeria } & 5 years & 16.57 & 18.39 & 5.44 & 10.83 & 0.30 & 0.47 & -1.72 \\
\hline & & [.014] & [.009] & {$[.006]$} & [.007] & {$[.020]$} & {$[.021]$} & [.029] \\
\hline \multirow[t]{2}{*}{ Sudan } & 5 years & 32.16 & 29.74 & 16.46 & 40.32 & 0.75 & 1.40 & -0.65 \\
\hline & & {$[.013]$} & {$[.008]$} & {$[.009]$} & {$[.009]$} & [.025] & {$[.022]$} & {$[.033]$} \\
\hline Tanzania & 5 years & 24.43 & 21.86 & 59.36 & 60.36 & 2.35 & 2.57 & -0.22 \\
\hline
\end{tabular}




\begin{tabular}{|c|c|c|c|c|c|c|c|c|}
\hline \multirow{3}{*}{ Vietnam } & \multirow{3}{*}{5 years } & [.024] & [.013] & [.025] & {$[.015]$} & [.088] & {$[.065]$} & [.109] \\
\hline & & 34.92 & 27.19 & 24.78 & 39.32 & 0.98 & 1.52 & -0.54 \\
\hline & & [.013] & [.009] & [.012] & [.007] & [.031] & [.024] & [.039] \\
\hline
\end{tabular}

* denotes significance at the 1\% level.

Note: The coefficient reported comes from regressing the number of shocks on region (urban/rural). All standard errors are reported within brackets 
Table 5: Location and shock type

Statistically significant pairwise correlations between shock type and rural/urban location

Type of household most likely to report experiencing shock

\begin{tabular}{|c|c|c|c|c|c|c|c|}
\hline Country & Price shocks & Disasters & $\begin{array}{c}\text { Employment } \\
\text { shocks }\end{array}$ & $\begin{array}{l}\text { Asset/crop } \\
\text { losses }\end{array}$ & Illness/death & Safety & $\begin{array}{c}\text { Household } \\
\text { breakup }\end{array}$ \\
\hline Afghanistan & Rural & Rural & & Rural & Rural & Rural & \\
\hline Bangladesh & & & & Rural & & Urban & \\
\hline Iraq & & & Urban & & & Rural & \\
\hline Lao PDR & & Rural & Urban & & & & \\
\hline Malawi & Rural & Rural & Rural & Rural & Rural & Urban & Rural \\
\hline Maldives & & & Urban & Urban & & & Urban \\
\hline Mexico & & Rural & Urban & Rural & Urban & Rural & \\
\hline Nigeria & & Rural & & & Rural & & \\
\hline Peru & & Rural & Urban & & Urban & & \\
\hline Sudan & & Rural & & Rural & Rural & Urban & \\
\hline Tanzania & Rural & Rural & Urban & Rural & Urban & Urban & Urban \\
\hline Uganda & & Rural & & & & & \\
\hline Uzbekistan & & & Rural & & Urban & Rural & \\
\hline Vietnam & & Rural & Urban & Rural & & & \\
\hline
\end{tabular}

Note: the words "rural" and "urban" indicate the sign of the coefficient for the urban/rural dummy when it was significant at $5 \%$ level or higher in a pairwise correlation between shock type and rural/urban location. 
Table 6: Coping responses

Percentage of households reporting responses conditional on having experienced a shock

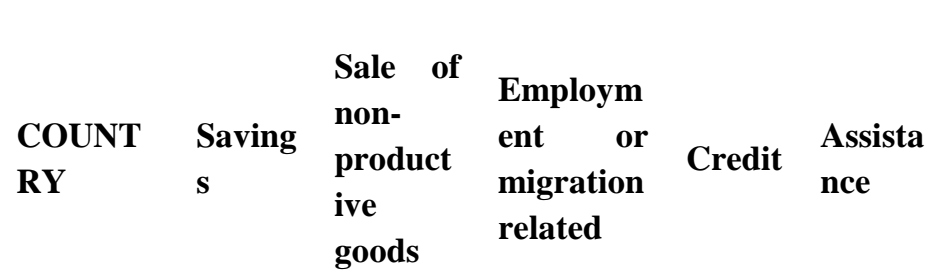

\section{Reductio}

$\begin{array}{lll}\mathbf{n} \text { in } & \text { Reductio } & \begin{array}{l}\text { Reductio } \\ \text { health }\end{array}\end{array}$ health $n$ in food $n$ in non- product Oth educatio consumpt

educatio consu spending

\begin{tabular}{|c|c|c|c|c|c|c|c|c|c|c|}
\hline $\begin{array}{l}\text { Afghanis } \\
\text { tan }\end{array}$ & 20.9 & 2.4 & 10.1 & 26.1 & 9.6 & 2.8 & 35.3 & 37.9 & 14.9 & 4.3 \\
\hline $\begin{array}{l}\text { Banglade } \\
\text { sh }\end{array}$ & - & 4.0 & - & 77.3 & - & - & - & - & 13.0 & 2.4 \\
\hline China & 20.4 & 3.0 & 51.0 & - & - & 5.5 & 56.3 & - & 10.2 & - \\
\hline Lao PDR & 18.4 & 0.7 & - & 2.2 & 4.4 & - & 43.8 & & 0.6 & 29.8 \\
\hline Malawi & 24.6 & 1.6 & 4.8 & 1.8 & 25.4 & - & 4.4 & 0.5 & 1.2 & 8.9 \\
\hline Nigeria & 3.9 & 8.8 & 16.1 & 36.5 & 33.3 & 2.9 & 21.3 & 12.9 & 19.9 & 8.6 \\
\hline Peru & 17.2 & 3.7 & 9.3 & 16.4 & 0.9 & - & 11.9 & & - & 10.6 \\
\hline Sudan & 14.3 & 10.4 & 20.4 & 15.2 & 23.6 & 0.6 & 4.2 & 2.8 & 13.7 & - \\
\hline $\begin{array}{l}\text { Tajikista } \\
\text { n }\end{array}$ & 9.2 & 3.8 & 47.9 & 25.5 & 34.1 & 16.9 & 28.9 & 59.7 & 23.6 & 23.3 \\
\hline Uganda & 33.2 & 3.0 & 23.5 & 12.0 & 21.7 & - & 38.7 & 0.5 & 4.7 & 34.4 \\
\hline
\end{tabular}

Note: Tanzania (2011) has no information on coping mechanisms. 
Note: We cannot distinguish between reductions in food and nonfood consumption for Lao PDR, Mexico, Peru and Vietnam.

Table 7: Household characteristics significantly associated with using various coping responses

\begin{tabular}{|c|c|c|c|c|c|}
\hline Country & $\begin{array}{c}\text { Use } \\
\text { savings/credit/ } \\
\text { assets }\end{array}$ & $\begin{array}{l}\text { Work } \\
\text { more/ } \\
\text { migrate }\end{array}$ & $\begin{array}{c}\text { Assistance } \\
\text { (government/family/community/NGOs) }\end{array}$ & $\begin{array}{l}\text { Sell } \\
\text { productive } \\
\text { assets }\end{array}$ & $\begin{array}{c}\text { Reduce } \\
\text { consumption } \\
\text { quantity/quality }\end{array}$ \\
\hline Afghanistan & Richer & Richer & Richer & Poorer & Poorer \\
\hline China & & Richer & & Richer & Richer \\
\hline Iraq & Richer & Richer & & & Poorer \\
\hline Malawi & Richer & & & & \\
\hline Mexico & $\begin{array}{l}\text { Poorer } \\
\text { (credit/asset } \\
\text { sales) }\end{array}$ & & & & Poorer \\
\hline Nigeria & Richer & & & & \\
\hline Peru & Richer & & & & \\
\hline Sudan & Richer & Poorer & Poorer & Poorer & Poorer \\
\hline Tajikistan & & & & Richer & Poorer \\
\hline Uganda & $\begin{array}{c}\text { Richer } \\
\text { (savings/sell } \\
\text { assets), poorer } \\
\text { (credit) }\end{array}$ & & Richer & & Poorer \\
\hline Uzbekistan & Poorer (credit) & Poorer & & Poorer & \\
\hline Vietnam & $\begin{array}{c}\text { Richer } \\
\text { (savings), } \\
\text { poorer (credit) }\end{array}$ & & Poorer & & Richer \\
\hline
\end{tabular}

Note: the words "poorer" or "richer" reflect the sign of the coefficient for the quintile variable when it was significant at 5\% level or higher. 


\section{Figure 1: Sources of shocks in Tanzania}

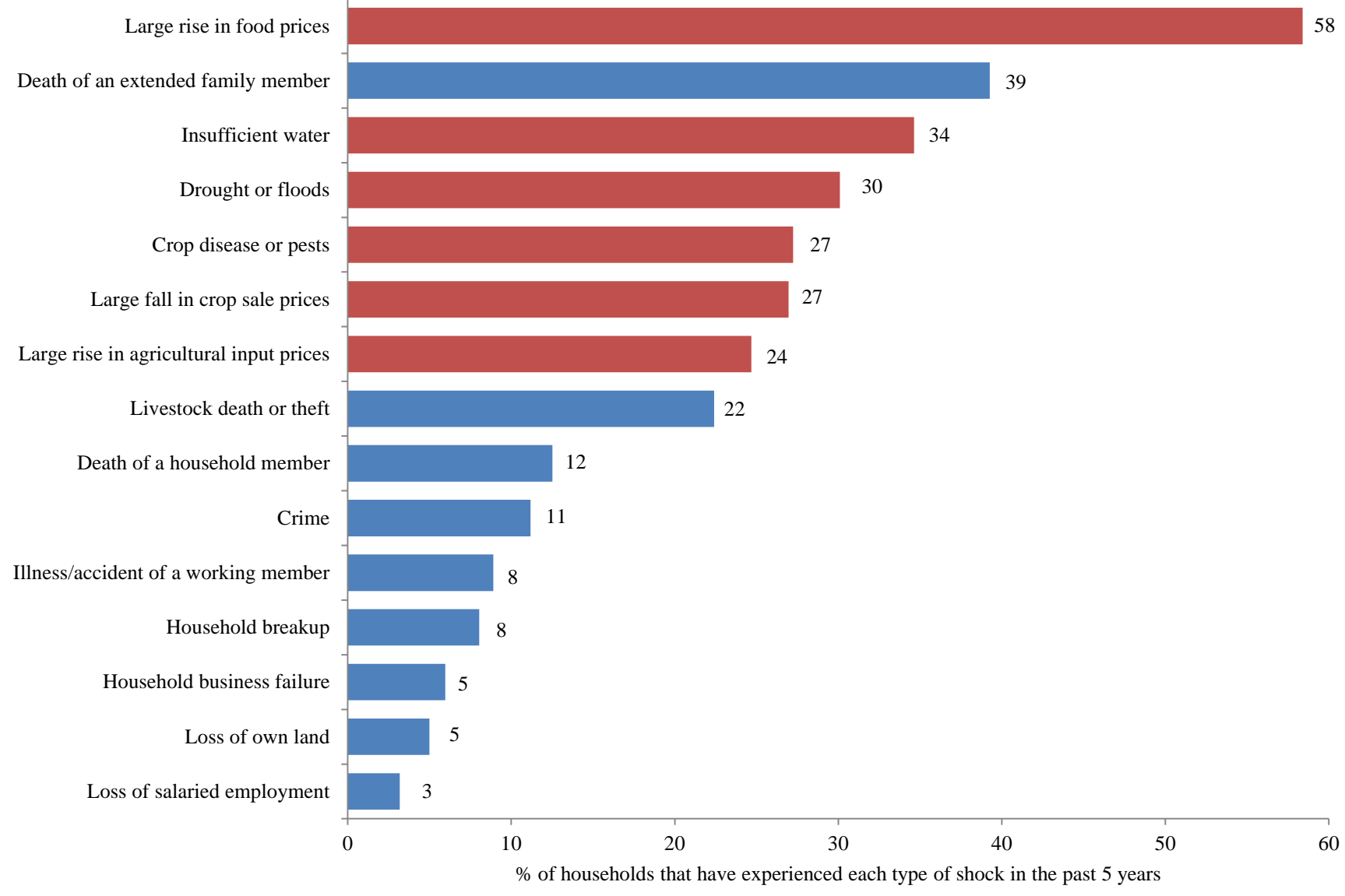

- Shock was mostly systemic (affected all/most other households in the community)

- Shock was idiosyncratic in most cases

Source: Authors based on data from the Tanzania National Panel Survey 2010/2011. 


\section{Figure 2 Responses to shocks}

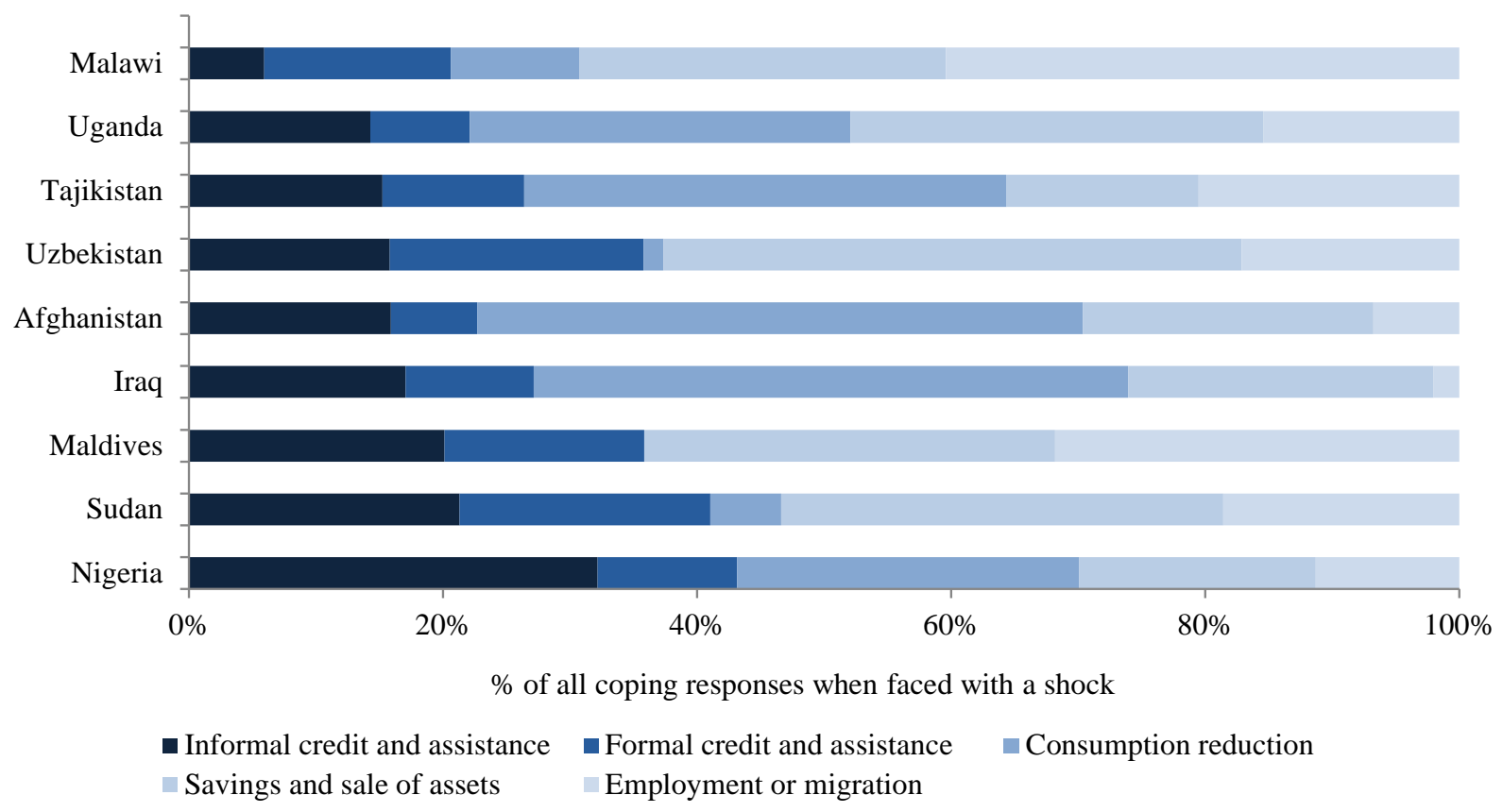

Source: Authors based on data from household surveys, various years 2004-11.

\footnotetext{
1 Jodha 1978, Hoddinott and Kinsey 2001, Dercon 2004, Little et al. 2004, Dercon et al. 2005, Christiaensen and Subbarao 2005, Alderman et al. 2006, Beegle et al. 2006, Porter 2012, Thai and Falaris 2014, Yilma et al., 2014.

${ }^{2}$ Comparing the share of households that have reported a price shock in the 2011 Tanzania survey to the district level price data for beans and maize (the major staple foods) from the World Food Program, we find that the correlation is positive and significant at the $1 \%$ level. This suggests that survey respondents' recall of price shocks reflects actual price increases.

${ }^{3}$ The full set of results are available from the authors upon request.

${ }^{4}$ See World Bank, 2013 figure 1.1 and 4.4 and http://www.worldvaluessurvey.org.
} 


\title{
What do Household Surveys Really Tell Us about Risk, Shocks, and Risk Management in the Developing World?
}

\author{
RASMUS HELTBERG*, ANA MARÍA OVIEDO* \& FAIYAZ TALUKDAR** \\ *Independent Evaluation Group (Heltberg) and Social Protection and Labor (Oviedo), The World Bank, Washington, DC, USA, \\ **Department of Economics, Georgetown University, Washington, DC, USA
}

\section{Online Appendix: Survey Design and Sampling}

This appendix documents various aspects of survey design and shock module content of the 16 countries in study. The common variables of interest in our study encompass all 16 surveys, and are thus presented in the body of the study text.

\section{Afghanistan National Risk and Vulnerability Survey (2005)}

In this survey, 30,822 households were sampled from 44 analytical domains based on a 'random start' method such that the sample was proportional to the population. Households were chosen using the governmental pre-Census list where available, and the 2003 FAO livestock census village list was used for households hailing from provinces not yet included in the census. The sample is nationally representative and has a recall period of one year. Household- and individuallevel surveys on socio-economic and community characteristics were collected between May and August. Survey respondents were generally the household head where available, the most informed adult household member was otherwise interviewed; female specific modules of the household survey (food consumption and maternal and child health) were answered by adult female household members only.

The shock module measures the incidence and intensity (ranking of the three most important shocks) of shocks stemming from reduced agricultural and drinking water quality and quantity, crop pests and/or disease, opium eradication and cultivation, livestock disease, violence, reduced availability of grazing areas and migration routes, earthquakes, landslides or avalanches, flooding, severe winter conditions, heavy rains, human disease, return migration, increase in food prices, decrease in farm gate prices, unemployment, salary reduction, serious illness and death of both working and non-working household members, theft and involuntary loss of land and livestock. The module asks for use of coping mechanisms in response to each shock, where the categories include reduction in quality and quantity of diet, decreased expenditures, sales of natural resources, spending savings or investments, loans from friends or family, loans from employers, moneylenders or NGOs, communal assistance, sale of durable assets and of income generating equipment, land rentals and mortgages, working for food and on relief programmes, out migration for new job prospects, joining the military, increasing child labour, sending sons off to work as indentured labour, selling child brides, begging and other case-specific responses. In addition, the module also asks about the impact of the shock on food consumption, and on perceived change in household economic situation. 


\section{Bangladesh Welfare Monitoring Survey (2009)}

A two-stage stratified cluster design was used to survey 14,000 households from 131 stratified regions (defined by the 2001 Population Census sampling frame). The sample is nationally representative and has a recall period of one year. Household- and individual-level surveys on socio-economic characteristics were collected in March. Survey respondents were generally the household head where available. There are no gender-specific modules in the survey.

The shock module measures the incidence of shocks stemming from business closure, crop loss, job loss, salary reduction, lack of external assistance, household breakup, special expenditures due to marriage, theft, eviction, legal difficulties, insecurity and/or extortion, death of a household member and other case-specific shocks. The module measures use of coping mechanisms in response to any shock experienced, including borrowing from relatives and/or friends, borrowing from moneylender or mortgaging property, borrowing from the bank, borrowing from an NGO, selling land, selling moveable properties, selling livestock and other case-specific responses. In addition, the module also collects information on the access to government assistance during any of the aforementioned crises.

\section{China Rural Social Protection Survey (2005)}

The survey uses a multistage sampling method to sample 6,165 households from 60 townships and 120 villages in the Gansu, Guangxi, Fujian and Zheijiang provinces. The sample is representative of the four provinces from which it was drawn, and has a recall period of one year. Household and individual level surveys on socio-economic characteristics were collected. The household head was the primary respondent when available. There are no gender-specific modules in the survey.

The shock module measures the incidence of shocks stemming from increased household size due to marriage and births, death and major illnesses of working and dependent household member/s, crop failure, livestock death, unemployment, theft and other case-specific shocks. The module asks about coping mechanisms used in response to shocks including using savings, eating stored grains, selling livestock, selling productive tools, selling furniture and/or other household property, living with relatives or friends, non-monetary assistance from friends and relatives, borrowing money from relatives, friends and/or banks, increasing workload, obtaining more work, child labour, discontinuing schooling, eating cheap food and reducing food consumption to its lowest possible level. In addition, the module also collects information on changes in welfare resulting from said shock, degree to which households have recovered from the crisis, as well as the source (relatives/friends/neighbours/other) of certain coping strategies (loans and assistance).

\section{Iraq Household Socio-Economic Survey (2006/2007)}

In this survey, 18,144 households were sampled using a two-stage stratified design from 3,024 Primary Sampling Units (defined by the 1987 Iraq Census) that cover each of Iraq's 432 governorates. The sample is nationally representative and has a recall period of one year. Household- and individual-level surveys on socio-economic characteristics were collected over a period of 12 months. The household head was the primary respondent when available; female specific modules of the household survey (maternal and child health) were answered by adult female household members only.

The shock module measures the incidence of shocks stemming from job loss, wage reduction, bankruptcy, severe illness or accident to any household member, death of working and/or dependent household members, theft, violence, kidnapping and other case-specific shocks. Coping responses include: reducing food quantity and quality; reducing expenditures; spending savings or investments; loans from family or friends; loans from employers; moneylenders or NGOs; buying food against credit; communal assistance; asset sales; selling income-generating equipment; renting or mortgaging land; selling land; selling supplies; relying on food/non-food assistance from rescue missions; 
migrating for work; joining the armed forces; child labour; increasing hours of work; sending sons into indentured labour; child bribes; begging; and other case-specific responses.

\section{Lao PDR Vulnerability and Shocks Survey (2008)}

In this survey, 600 households were randomly sampled from 20 communities by Probability Proportion to Size (PPS) in the Attapeu, Phongsaly and Viantiane provinces. The survey is representative of the three surveyed provinces and has a recall period of one year. Householdand individual-level surveys on socio-economic characteristics were collected between March and April. The household head was the primary respondent when available; the shock module was the sole exception to the rule where both the household head and spouse were asked to respond. There are no gender-specific modules in the survey.

The shock module measures the incidence and timing of shocks stemming from drought, floods, earthquakes, extreme cold or heat, crop and livestock disease, fall in prices of commodities sold, increase in input prices, increase in food prices, job loss, extended unemployment, non-payment or delay in salary payment, crime, ethnic or religious conflict, property confiscation or forced resettlement, household issues, and serious illness, injury or death. The module asks how shocks were coped with; with response categories including savings, loans from a bank, employer, friend or relative, selling assets and/or goods, selling harvest in advance, delaying future plans, cutting down consumption of food and/or non-food goods, seeking governmental and/or non-governmental assistance, and seeking communal assistance. In addition, the module also asks respondents about negative repercussions arising from the shock, as well as the degree to which households have recovered from said shock.

\section{Malawi Third Integrated Household Survey (2010/2011)}

In this survey, 12,271 households were surveyed using a two-stage stratified design (based on the 2008 Population and Census sampling frame) from 31 districts across the three major regions of Malawi. The sample is nationally representative, and has a recall period of one year. Household- and individual-level surveys on socio-economic and community characteristics were collected from March 2010 to March 2011. The household head was the primary respondent when available; adult female household members were exclusively interviewed for questions pertaining to child health.

The shock module measures the incidence and ranking of shocks stemming from drought, floods, earthquake, crop pests or disease, livestock disease, low prices for agricultural output, high input prices, high food prices, lack of external assistance, fall in business earnings, business failure, reduction in wages, job loss, serious illness or accident, birth in the household, death of earning and/or dependent household members, household break-up, theft, violence and other case-specific shocks. Coping options include using savings, receiving assistance from friends, family, government or non-governmental institutions, changing eating patterns, increasing self-employment, increasing the number of household members employed, migrating, reducing health and/or education expenditures, obtaining credit, selling agricultural and/or durable assets, selling land, crop stock and/or livestock, intensifying fishing, sending children off to live elsewhere, engaging in spiritual efforts and not doing anything. In addition, the module also asks about changes in household welfare stemming from the shock.

\section{Maldives Vulnerability and Poverty Survey (2004)}

In this survey, 2,840 households were sampled from all 200 inhabited islands using multi-stage systematic sampling with a random start. The sample is nationally representative, and has a recall period of five years. A questionnaire on household and individual characteristics pertaining to 
various indicators of vulnerability was collected in 2004 between May and July. Survey respondents were generally the household head where available. There are no gender-specific modules in the survey.

The shock module measures the incidence, frequency and timing of shocks stemming from death of an earning and/or dependent household member, expenses due to major illness, injury and/or accident, joblessness, fire damage, crop damage, loss/damage of fishing boats and/or equipment, household break-up, legal expenses and other case-specific shocks. The module measures coping mechanisms: savings, income; insurance; government support; borrowing from friends and relatives; borrowing from banks and other institutions; selling productive assets; selling goods; and other case-specific responses. In addition, the module asks about expenses associated with and forgone income due to the crisis.

\section{Mexico Family Life Survey (2002)}

In this survey, 8,440 households were sampled using the 2002 Mexican National Employment Survey sampling framework. The sample is representative at the national level and has a recall period of five years. Household- and individual-level surveys on socio-economic characteristics were collected in 2002. Additional information on community characteristics was also collected. The household head was the primary respondent when available; adult female household members were exclusively interviewed for questions pertaining to reproductive health.

The shock module measures the incidence, frequency and timing of shocks stemming from death, illness or accident, unemployment or business failure, natural disasters and crop loss. Coping options comprise: savings; receiving aid from relatives and/or friends; borrowing; selling goods; working more hours; taking on different types of work; obtaining additional job/s; decreasing school attendance; starting/selling a business; and other case-specific responses. In addition the module also asks about which family members were directly affected by the shock.

\section{Nigeria General Household Survey 201020/11}

In this survey, 4,986 households were sampled using a two-stage sampling design (constructed using the 2006 Housing and Population Census sampling frame) from 500 Primary Sampling Units by PPS. The survey is representative at the national level, and has a recall period of five years. Household- and individual-level surveys on socio-economic, agricultural and community characteristics were collected from late 2010 to early 2011. The household head was the primary respondent when available; adult female household members were exclusively interviewed for questions pertaining to food preparation and/or purchases.

The shock module measures the incidence, frequency, ranking and timing of shocks stemming from death/disability of a working household member, death of a remitter, illness of a working member, loss of an important contact, job loss, household break-up, business failure, theft, harvest destruction, dwelling damage, poor rains, flooding, pest invasion, property loss due to natural disasters, land loss, livestock death, increase in input prices, fall in output prices, increase in food prices, insecurity and other case-specific shocks. Coping options include: selling livestock and/or land; selling other property; sending children to live elsewhere; withdrawing children from school; increasing income earning activities; receiving assistance from friends and relatives; borrowing from friends and relatives; taking a loan from a financial institution; migrating for work; crediting purchases; delaying payment obligations; selling harvest in advance; reducing food and/or non-food consumption; relying on savings; receiving assistance from NGOs; taking advanced payment from employer; receiving assistance from the government; insurance coverage; and other case-specific responses. In addition, the module asks about welfare consequences arising from, as well as which household members were most affected by, the shock. 


\section{Perú Encuesta Nacional de Hogares Sobre Condiciones de Vida y Pobreza (2011)}

In this survey, 26,456 households were sampled from 3,989 clusters using a three-stage stratified design (the framework is based off the 2007 Population and Housing Census). The survey is representative at the national level, and has a recall period of one year. Household- and individuallevel surveys on socio-economic characteristics and governance were collected in 2010 between October and December. The household head was the primary respondent when available; adult female household members were exclusively interviewed for questions pertaining to reproductive health.

The shock module measures the incidence of shocks stemming from unemployment, business bankruptcy, serious illness or accident, household break-up, theft and natural disasters. The module asks about coping mechanisms used: savings; pawning goods; obtaining loans; working more jobs; receiving government assistance; decreasing consumption; and other case-specific responses. In addition, the module asks about welfare consequences stemming from the shock through income and/or asset reductions.

\section{Sudan National Baseline Household Survey (2009)}

In this survey, 7,920 households, defined by the 2008 Population and Housing Census, were sampled using a two-staged stratified design. The survey is nationally representative and has a recall period of five years. Household- and individual-level surveys on socio-economic characteristics were collected in May. The household head was the primary respondent when available. There are no gender-specific modules in the survey.

The shock module measures the incidence and ranking of shocks stemming from drought or floods, crop disease or pests, livestock death or theft, severe illness or accident in the household, death of a household member, fire, robbery or assault, dwelling damages, severe water shortage and other casespecific shocks. Response categories for coping comprise savings, sending children to live with relatives, selling assets, selling land, renting out farm, selling animals, selling more crops, working more, sending previously unemployed household members to work, starting a new business, removing children from school, migrating for work, borrowing money from relatives, moneylenders and/or institutions, receiving help from religious institutions, NGOs, government, friends and/or family, reducing food consumption, consuming cheaper goods, reducing non-food expenditures, spiritual help and other case-specific responses. In addition, the shock module asks about the estimated cost arising due to the shock.

\section{Tajikistan Living Standards Measurement Survey (2009)}

In this survey, 1,500 households were sampled across 270 clusters defined by the 2000 Population Census, where the sample design comes from the 2005 Tajikistan Multiple Indicator Cluster Survey. The survey is nationally representative and has a recall period of one year. Household- and individuallevel surveys on socio-economic characteristics were collected in November. The household head was the primary respondent when available. There are no gender-specific modules in the survey.

The shock module does not ask questions about the incidence of shocks. Rather, the module only asks about coping in response to any shock experienced such as asking friends or family for money, borrowing from a moneylender, sending a household member to work, increasing food production for own consumption, switching to less expensive or not buying certain non-food items, buying secondhand items, using less entertainment services, using fewer information services, meeting with friends less, transferring children to a public or cheaper school, withdrawing household member from school, leaving training courses, using public health facilities instead of private health care, cancelling house, car and/or health insurance, increasing public transport usage, reducing trips to the doctor, stopping sports activities, spending savings, pawning goods, cashing in securities, working more hours, selling 
livestock, selling harvest in advance and sending previously unemployed household members to work. In addition, the module also asks about subjective improvement to future household welfare.

\section{Tanzania National Panel Survey (2010/2011)}

In this survey, 3,924 households drawn from clusters defined by the 2002 Population Census were sampled using a multi-stage clustered design. The survey is nationally representative and has a recall period of five years. Household- and individual-level surveys on socio-economic and community characteristics were collected from October 2010 to September 2011. The household head was the primary respondent when available; household members were exclusively interviewed for questions pertaining to their respective health.

The shock module measures the incidence, timing and ranking of shocks stemming from drought or floods, crop disease or pests, livestock death or theft, business failure, unemployment or non-payment of salary, fall in output prices, rise in input prices, rise in food prices, severe water shortage, land loss, severe illness or accident in the household, death of a family member, household break-up, jail, fire, robbery or assault, dwelling damages and other case-specific shocks. In addition, the module asks about welfare changes arising from the shock, and about the degree of dispersion of each shock experienced. The module does not ask questions about coping measures.

\section{Uganda National Household Survey (2009/2010)}

In this survey, 6,800 households were drawn from 712 PSUs (selected using the 2002 Population and Housing Census) using a two-stage stratified sampling design. The survey is representative at the national level and has a recall period of one year. Household- and individual-level surveys on socioeconomic and community characteristics were collected from May 2009 to April 2010. The household head was the primary respondent when available; adult female household members were exclusively interviewed for questions pertaining to contraception and reproductive history.

The shock module measures the incidence, timing and length of shocks stemming from drought, floods, landslides, crop pests and disease, livestock disease, high input prices, low output prices, reduced wages, unemployment, serious illness or accident within the household, death of an earning or dependent household member, theft of assets, conflict, fire and other case-specific shocks. Coping options comprise: assistance from friends; relatives or local government; changing dietary patterns involuntarily; changing cropping practices; taking on additional employment; migrating for work; using savings; obtaining credit; selling assets; selling land; renting out land; selling livestock; sending children out to live elsewhere; reducing expenditures on health and education; and other case-specific responses. In addition, the module also asks about welfare repercussions arising from the shock.

\section{Uzbekistan Regional Panel Survey (2005)}

In this survey, 2,948 households were selected using a three-stage stratified design from the Andijan and Kashkadarya regions, where the framework is based off the 2002 State Statistical Committee's countrywide population review. The sample is not nationally representative and has a recall period of one year. Household- and individual-level surveys on socio-economic and community characteristics were collected between June and July. The household head was the primary respondent when available. There are no gender-specific modules in the survey.

The shock module measures the incidence of shocks stemming from serious illness or disability within the household, decrease or loss of remittances, job loss, property loss, harvest loss, business failure, wedding expenses, discontinuation of allowance payments, low salary or allowances, delay in salary or allowance payments and other case-specific shocks. Coping options comprise: savings; selling property; obtaining help from other households; increasing work activities; taking children 
out of school; using insurance; migrating; settling with a different household; and other case-specific responses. In addition, the module also asks about welfare repercussions arising from the shock and changes in wellbeing via usage of coping mechanisms (of which the top three are ranked).

\section{Vietnam Household Living Standard Survey (2008)}

In this survey, 45,495 households from 3,063 communes were surveyed using the sampling frame designed for the Vietnam Living Standard Survey. The survey is nationally representative and has a recall period of five years. Household- and individual-level surveys on socio-economic and community characteristics were collected in May. The household head was the primary respondent when available. There are no gender-specific modules in the survey.

The shock module measures the incidence and timing of shocks stemming from drought, floods, earthquake or tsunami, crop and livestock disease, fall in output prices, rise in input prices, rise in the price of essentials, unemployment, late debt payment, crime, deceit, law violation, gambling loss, foreclosure or mandatory relocation, household break-up, serious illness, accident or death within the household and other case-specific shocks. The module similarly measures use of coping mechanisms in response to any shock experienced, including assistance from NGOs, government, friends and/or family, borrowing from a bank, employer, moneylender, friends and/or family, using savings, delaying investments, selling assets, selling harvest in advance, pawning goods, cutting down on consumption and other case-specific responses. In addition, the shock module asks about welfare repercussions arising of the shock, whether the household has recovered from the shock, and which household members were most affected. 